\title{
Succession and disturbance in an endangered red spruce-Fraser fir forest in the southern Appalachian Mountains, North Carolina, USA
}

\author{
Philip B. White, Saskia L. van de Gevel* ${ }^{*}$ Peter T. Soulé \\ Department of Geography and Planning, Appalachian Tree Ring Lab, Appalachian State University, Boone, \\ North Carolina 28608, USA
}

\begin{abstract}
Red spruce-Fraser fir forests are geographically limited to high elevations in the Appalachian Mountains (USA) and are considered to be endangered in the USA. We investigated the successional status and radial growth patterns in the heavily disturbed red spruce Picea rubens Sarg. and Fraser fir Abies fraseri (Pursh) Poir. forest of Roan Mountain, Tennessee and North Carolina. This study elucidates the complexity of second-growth red spruce development after logging and disturbances by balsam woolly adelgid Adelges piceae Ratz. We documented precise temporal information of stand age, disturbance regimes, recruitment patterns, and the successional trajectory of the spruce-fir forest community. We used radial growth patterns of red spruce samples to detect the frequency and magnitude of disturbance. Red spruce was the oldest dominant canopy species, although Fraser fir had high recruitment rates over the past $80 \mathrm{yr}$. Changes in forest structure and species richness coincided with stand-wide disturbance events such as balsam woolly adelgid infestation and widespread early twentieth-century logging. The competitive advantage of Fraser fir over red spruce has resulted in an even-aged Fraser fir-dominant forest that occupies a relatively early stage of successional development. This study provides a $130 \mathrm{yr}$ environmental history to assist land managers in the southern Appalachian Mountains as they develop long-term restoration plans for this unique ecosystem.
\end{abstract}

KEY WORDS: Disturbance - Spruce-fir forest - Dendroecology - Stand dynamics - Logging · Balsam woolly adelgid

\section{INTRODUCTION}

The red spruce Picea rubens Sarg. and Fraser fir Abies fraseri (Pursh) Poir. forests of the southern Appalachian Mountains are ranked as the second most endangered ecosystem in the USA (Noss et al. 1995, Christensen et al. 1996, Rentch et al. 2007). Within the eastern USA, these subalpine forests have undergone a major shift in structure and composition during the past several decades (Johnson \& Siccama 1983, Cook et al. 1987, Dull et al. 1988, Eagar \& Adams 1992, Goelz et al. 1999, Busing 2004, Rentch et al. 2007, 2010). There is concern about the resilience and vigor of the red spruce-Fraser fir (RSFF) ecosystem (Wear \& Greis
2002, Rentch et al. 2007), as anthropogenic activities have altered disturbance vectors and successional patterns. The forest community exists in only a few disjunct, island populations at high elevations in the southern Appalachian Mountains. The RSFF forest has greater plant diversity than similar northern forests (Delcourt \& Delcourt 2000), and sustains several endemic, endangered species such as the Carolina northern flying squirrel Glaucomys sabrinus coloratus, spruce-fir moss spider Micohexura montivaga, Roan Mountain bluet Hedyotis purpurea var. montana, and rock gnome lichen Gymnoderma lineare (Rentch et al. 2010). This forest type is highly valued by ecologists, park and land managers, and the public. 
During the mid-20th century, scientists observed widespread growth decline and tree mortality in RSFF forests (Hornbeck \& Smith 1985, Adams \& Eagar 1992). The balsam woolly adelgid Adelges piceae Ratz., an exotic insect that kills mature Fraser fir trees, has cyclically infested southern Appalachian Mountain Fraser fir forests since the 1950s, affecting most RSFF forests (Boyce \& Martin 1993, M. Pyne \& D. Durham unpubl. data). Mortality rates for mature Fraser fir trees are high (Dull et al. 1988), and the species is becoming increasingly less dominant (Busing et al. 1993, Busing 2004).

Human disturbance during the 19th and 20th centuries has affected the forest health and successional trajectory of southern Appalachian Mountain forests. Spruce-fir forests were altered by the aggressive logging practices, burning, and subsequent soil erosion which were common in the region during the late 1800s and early 1900s (Pyle 1984, McLaughlin et al. 1991). The great economic value of red spruce lumber during the early 1900s led to heavy logging with little long-term management planning (Korstian 1937, Pyle 1984, Hayes et al. 2007). RSFF forests were selectively logged or clear-cut. Extensively logged spruce-fir forests include the Great Smoky Mountain National Park of Tennessee and North Carolina, the Balsam Mountains, the Black Mountains, Grandfather Mountain, the Plott Balsams, and Roan Mountain in North Carolina; and Mount Rogers, Virginia (Pyle \& Schafale 1988, Smith \& Nicholas 1999, Hayes et al. 2007). Pyle (1984) found that as much as $50 \%$ of all Appalachian spruce-fir forests were replaced by hardwood species after logging.

Among the highest peaks of the southern Appalachian Mountains, Roan Mountain hosts one of the few remaining RSFF forest communities. Located at the boundary between Tennessee and North Carolina, the Roan Massif area and its spruce-fir forests are over 1650 m elevation. Logging began on Roan Mountain during the late 1800 s, but was minimal relative to the aggressive logging during the 1920s and 1930s when the area was clear-cut, removing trees larger than $15 \mathrm{~cm}$ in diameter (Wilson 1991). Logging lasted until 1937 and effectively denuded the highest elevations of Roan Mountain (Wilson 1991). In 1941, the USDA Forest Service purchased approximately 2800 ha atop Roan Mountain, granting protection to the area's endangered spruce-fir forest (Wilson 1991). Logging has not occurred on Roan Mountain since the USDA Forest Service acquired the land.

Previous studies have focused on spruce-fir forests in the central Appalachian Mountains, but few studies have examined this forest ecosystem in the south- ern Appalachian Mountains, where endemic endangered species are present. In the present study, we quantified the spruce-fir forest age, the current forest composition, and the successional trajectory of the spruce-fir forest on Roan Mountain in the southern Appalachian Mountains. The primary objectives were to (1) quantitatively document the current composition and structure of Roan Mountain's RSFF forest, (2) use dendroecological techniques to investigate the forest's disturbance history and to elucidate its pre-logging composition, and (3) determine how land use and disturbance history have affected the successional development of this forest.

\section{MATERIALS AND METHODS}

\section{Study area}

Roan Mountain is a part of the Unaka Mountains, a subset of the southern Appalachian Mountains and part of the Blue Ridge physiographic province (Clark 2008). The mountain is located at approximately $36^{\circ} 6^{\prime} 16.42^{\prime \prime} \mathrm{N}, 82^{\circ} 7^{\prime} 47.39^{\prime \prime} \mathrm{W}$, its ridgeline delineating the state border between Tennessee and North Carolina (Fig. 1). Roan Mountain (including Roan High Bluff and Roan High Knob) encompasses approximately $19 \mathrm{~km}^{2}$. The entire Roan Massif, however, is much larger and extends along the North Carolina-Tennessee border for approximately $30 \mathrm{~km}$. Much of the massif is jointly managed by Pisgah National Forest in North Carolina and Cherokee National Forest in Tennessee. Roan Mountain's high elevations are classified as Cfb (marine temperate climate) under the Köppen climate classification system (Christopherson 2006), based on the cooler temperatures and increased precipitation associated with high elevation and orographic uplift (Christopherson 2006). Soils are primarily well-drained Inceptisol loams that form on steep, rocky slopes and ridge tops (NRCS 2010).

The Roan Mountain spruce-fir forest was surveyed prior to 1930s logging (Brown 1941) and RSFF were found to represent $89.2 \%$ of all trees (62.3\% Fraser fir and $26.9 \%$ red spruce). Yellow birch Betula alleghaniensis Britt., mountain maple Acer spicatum Lam., American beech Fagus grandifolia Ehrh., mountain ash Sorbus americana Marsh., yellow buckeye Aesculus octandra Aiton, and pin cherry Prunus pensylvanica L. were also present. Although Fraser fir had the highest density, red spruce had the highest basal area. Fraser fir was the most common tree in the understory (Brown 1941). 


\section{Field methods}

We established 6 circular 0.05 ha fixed-radius plots ( $\mathrm{r}=12.66 \mathrm{~m}$ ) within RSFF codominant stands to study forest composition, canopy structure, and forest disturbance patterns. All plots were located approximately $1800 \mathrm{~m}$ or higher in uneven-aged stands. We targeted stands with a variety of age classes to develop a historical timeline of disturbance events. Plots were separated by at least $100 \mathrm{~m}$ and were downslope from the generally southwest to northeast trend of the ridgeline. We measured the location, percent slope, and aspect of each plot. We collected increment cores from all trees $\geq 10 \mathrm{~cm}$ diameter at breast height ( $\mathrm{DBH}, 1.37 \mathrm{~m}$ above ground) to determine tree age. We cored trees close to the ground to obtain the maximum amount of growth rings (Fritts 1976). Cores with extensive rot and decay were discarded, but these were relatively few in number.

We inventoried tree species and canopy classes of trees $\geq 10 \mathrm{~cm}$ DBH. We categorized canopy position based on the amount and direction of intercepted light and designated each tree as occupying either dominant, codominant, intermediate, or suppressed positions (Oliver \& Larson 2002). In each overstory plot, we established a fixed-radius 0.01 ha $(r=5.66)$ nested sub-plot to evaluate regeneration of tree species in the understory. All saplings (woody stems $<10 \mathrm{~cm} \mathrm{DBH}, \geq 1 \mathrm{~m}$ height) were tallied by species

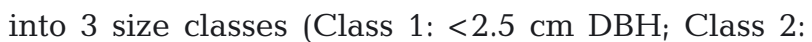
2.5-4.9 cm DBH; Class 3: 5.0-9.9 cm DBH).

\section{Laboratory methods}

Increment cores were processed following standard dendroecological techniques (Stokes \& Smiley 1996). We dated and crossdated all tree cores. Most cores intersected or very nearly intersected the tree's pith. We calculated density, basal area (dominance), and importance values of each tree species (Cottam \& Curtis 1956, Ludwig \& Reynolds 1988, Matthews \& Mackie 2007, Hart et al. 2008). Importance values were calculated as the sum of the relative density and relative dominance.

We measured annual growth rings from red spruce cores to the nearest $0.001 \mathrm{~mm}$ with a Velmex measuring system coupled with Measure J2X software. The crossdating accuracy of each red spruce series was then statistically verified against all other red spruce series using the computer program COFECHA and 30 yr segments lagged successively by 15 yr (Holmes 1983, Grissino-Mayer 2001).

We standardized all series in the red spruce chronology to remove effects from age-related growth trends that could add noise to the series unrelated to the climate signal desired in chronology development (Fritts 1976). We removed the age-related growth trend of each sample using the

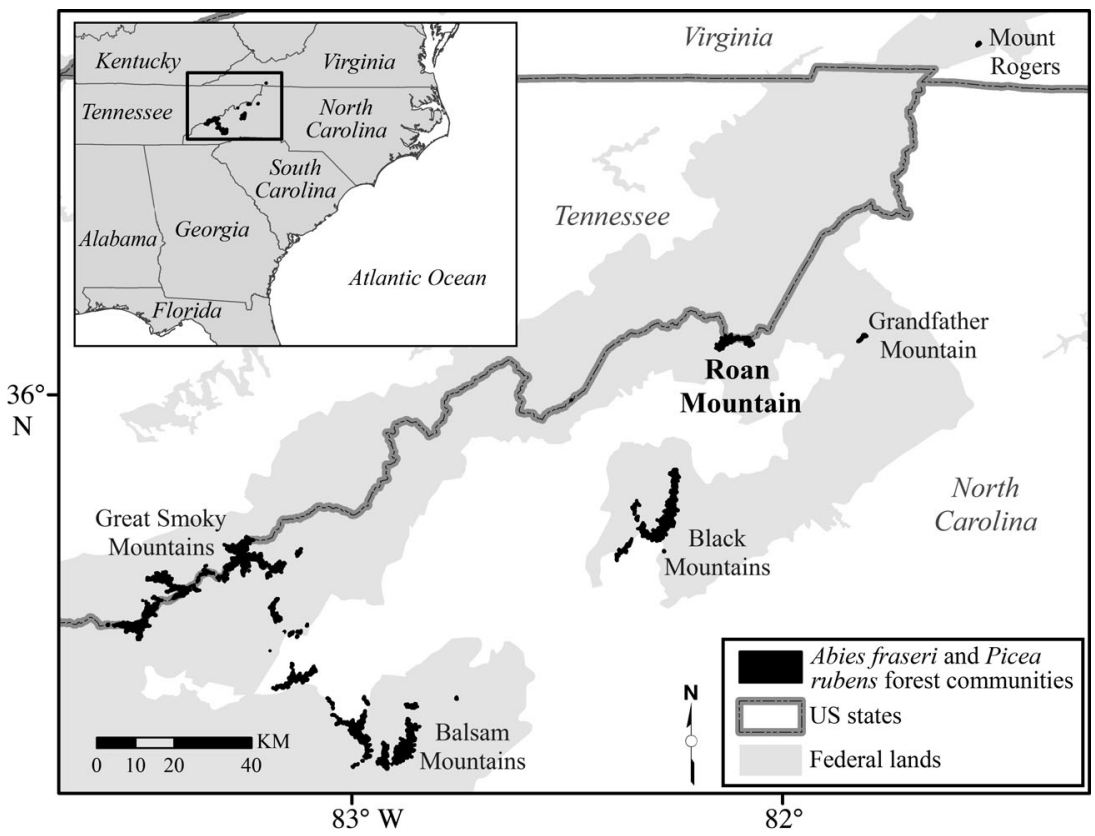

Fig. 1. Picea rubens and Abies fraseri. Red spruce and Fraser fir high-elevation forest islands in the southern Appalachian Mountains, USA. The present study was conducted on Roan Mountain in North Carolina program ARSTAN (Cook 1985), which fits a negative exponential trend line to the growth of the sample using the least squares technique. ARSTAN then creates an index for that year by dividing the actual ring width by the value predicted by the regression (Fritts 1976, Cook 1985). The indices were then averaged for each year across all series to create a single red spruce chronology (Fritts 1976).

The detection of release events in trees is a common approach for inferring the disturbance history of a forest community (Lorimer \& Frelich 1989, Rubino \& McCarthy 2004, Hart et al. 2008). A release event is defined as a period in which radial growth abruptly increases over a period of successive years (Nowacki \& Abrams 1997, Rubino \& McCarthy 2004). Release events occur following a canopy disturbance (Fraver \& White 2005). We 
used the computer program JOLTS to identify release events in red spruce tree-ring measurement series (Holmes 1999). The JOLTS program analyzes raw ring-width measurement values to identify release events based upon user-defined parameters. We analyzed changes in ring width using a 10 yr running average of the previous and subsequent $10 \mathrm{yr}$. We specified release detection parameters of $100 \%$ for a major release, $50 \%$ for a moderate release, and $25 \%$ for a minor release, with a minimum of $5 \mathrm{yr}$ between each release event. For example, a major release event had a ring width 2.0 times greater than the average of the preceding and following $10 \mathrm{yr}$. A release event was defined as a stand-wide disturbance if $25 \%$ or more of all trees experienced a release in a given year (Nowacki \& Abrams 1997, Rubino \& McCarthy 2004). These synchronous release events were indicative of a large-scale exogenous disturbance, while asynchronous events (fewer than $25 \%$ ) were considered localized and related to single tree deaths (Orwig \& Abrams 1994).

\section{RESULTS}

\section{Stand composition and age structure}

The dominant species above $1800 \mathrm{~m}$ at Roan Mountain was Fraser fir, accounting for $83.21 \%$ of all trees, with the highest relative dominance and importance scores (Table 1). The other common species was red spruce, and together, Fraser fir and red spruce comprised $98.62 \%$ of the trees, with combined relative dominance and importance values of $99.58 \%$ and $99.1 \%$ for spruce and fir, respectively. Hardwood species present included mountain ash, pin cherry, and yellow birch (Table 1). Fraser fir was also the dominant species in every canopy class (Fig. 2). Most trees were in the codominant canopy position (of which $83.8 \%$ were Fraser fir and $15.6 \%$ were red spruce). The high density of Fraser fir compared to red spruce remained consistent among all other canopy classes. In the understory, Fraser fir accounted for $85.92 \%$ of all saplings, dominating all size classes (Table 2). We calculated 4734 saplings $\mathrm{ha}^{-1}$ from the sapling size classes. Mountain ash was the second most frequent species in the sapling survey. Red spruce was not a common understory species.

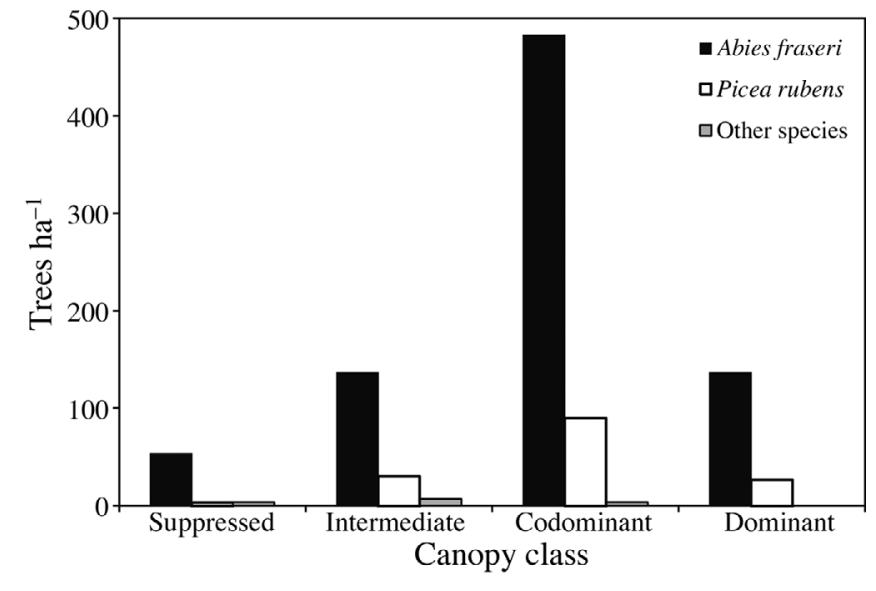

Fig. 2. Canopy positions of tree species surveyed in spruce-fir forest plots at Roan Mountain, North Carolina: red spruce Picea rubens, Fraser fir Abies fraseri; other species include yellow birch Betula alleghaniensis, mountain maple Acer spicatum, American beech Fagus grandifolia, mountain ash Sorbus americana, yellow buckeye Aesculus octandra, and pin cherry Prunus pensylvanica

Age structure analysis revealed a distinct shift in forest composition during the late 1930s and early 1940s, coinciding with the cessation of logging activities (Fig. 3). This period marked a change from a red spruce-dominated forest to a densely populated Fraser fir forest with fewer red spruce trees. A few red spruce trees established prior to intensive logging. The oldest tree in the stand was a red spruce that was at least $136 \mathrm{yr}$ old, and the oldest Fraser fir was $109 \mathrm{yr}$ old. Of all red spruce trees, 55.56\% had pith dates before 1937, which coincided with the final year of logging operations, while $82.77 \%$ of all Fraser fir trees sampled had pith dates of 1937 or later. Although the post-logging pulse in tree establishment was found for Fraser fir and red spruce trees, 
Table 2. Abies fraseri, Picea rubens, and Sorbus americana. Sapling summary statistics for Fraser fir, red spruce, and mountain ash (Class $1=<2.5 \mathrm{~cm}$ diameter at breast height, $\mathrm{DBH}_{;}$Class $2=2.5-4.9 \mathrm{~cm} \mathrm{DBH} ;$ Class $\left.3=5.0-9.9 \mathrm{~cm} \mathrm{DBH}\right)$

\begin{tabular}{|c|c|c|c|c|c|c|}
\hline \multirow[t]{2}{*}{ Species } & \multicolumn{3}{|c|}{ Class } & \multirow[t]{2}{*}{ Total } & \multirow{2}{*}{$\begin{array}{l}\text { Sapling } \\
\text { density } \\
\text { (ind. ha }{ }^{-1} \text { ) }\end{array}$} & \multirow{2}{*}{$\begin{array}{c}\text { Relative } \\
\text { density } \\
\mathrm{ha}^{-1}\end{array}$} \\
\hline & 1 & 2 & 3 & & & \\
\hline Abies fraseri & 127 & 99 & 18 & 244 & 4067.48 & 85.92 \\
\hline Picea rubens & 7 & 8 & 1 & 16 & 266.72 & 5.63 \\
\hline $\begin{array}{l}\text { Sorbus } \\
\text { americana }\end{array}$ & 23 & 1 & 0 & 24 & 400.8 & 8.45 \\
\hline Total & 157 & 108 & 19 & 284 & 4734.28 & 100 \\
\hline
\end{tabular}
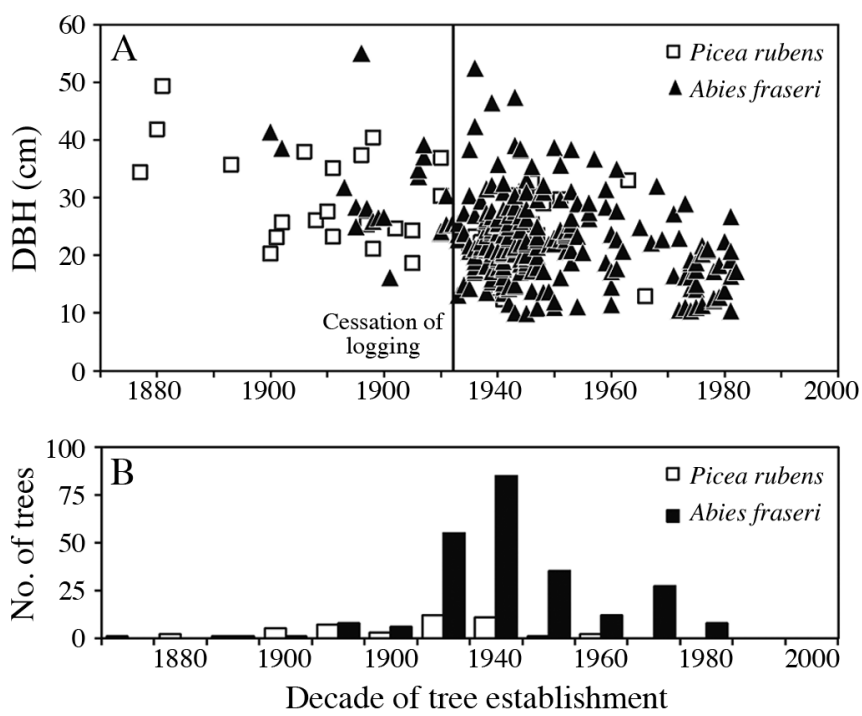

Fig. 3. Picea rubens and Abies fraseri. (A) Age-diameter relationships of 286 red spruce and Fraser fir trees at Roan Mountain, North Carolina. The black vertical line indicates the cessation of logging and subsequent pulse in tree establishment. (B) Decade of establishment of the red spruce and Fraser fir trees. DBH: diameter at breast height

Fraser fir density was higher. Among all trees sampled, $91.17 \%$, of which $90.78 \%$ were Fraser fir, had post-logging pith dates. Following the post-logging establishment period, tree establishment gradually decreased until a second, smaller establishment pulse occurred during the 1970s and 1980s. The second tree establishment pulse was mostly Fraser firs.

\section{Disturbance history}

Most Fraser firs established post-logging. All Fraser fir trees exhibited prolonged radial growth characteristics that reflect release episodes during the period immediately following logging. We omit- ted Fraser firs from further release analysis because the trees exhibited erratic juvenile growth and were less than 80 yr old. We analyzed 26 red spruce series for radial growth changes and release events (Figs. 4 $\& 5)$. Of these, 23 trees (88\%) experienced 91 release events that were at least minor (25\% increase; Table 3). Most red spruce experienced multiple release events, with a mean of 3.96 release events per tree. Fewer red spruce trees experienced moderate or major events. We found 62 moderate release events in 21 trees and 29 major release events in 13 trees. Stand-wide release events occurred periodically and only at minor and moderate release levels (Fig. 4). We found minor and moderate stand-wide events in 1935, 1940, and 2000. The most widespread release events occurred during the 1930s and 1940s as a result of logging activities. Radial growth releases related to logging lasted for over 2 decades and gradually diminished during the 1950s. The greatest stand-wide event occurred in 2000, when $25 \%$ of trees experienced moderate releases and $50 \%$ of trees experienced minor releases.

\section{DISCUSSION}

The RSFF forest at Roan Mountain experienced significant changes during the 20th century. Red spruce and Fraser fir shared dominance in the prelogging forest, but the more rapidly regenerating Fraser fir was the dominant tree in the post-logging forest. Fraser fir benefitted from clear-cut logging during the 1920s and 1930s, as the establishment of new Fraser firs dramatically outnumbered red spruce establishment during the post-logging period. Although we detected a spruce-fir establishment cohort post-logging, Fraser fir overwhelmingly dominated this establishment pulse, and red spruce was largely absent from subsequent pulses in recruitment. Fraser fir dominance over red spruce following disturbance is expected, as red spruce is shade tolerant (Busing et al. 1988, Smith \& Nicholas 2000, Busing 2004). The modern Fraser fir-dominated forest was largely an even-aged stand that established during the late 1930s and 1940s. Older individuals that were not logged likely exhibited irregular growth forms or were too small, making them undesirable to loggers. The contrast between the pre-logging and post-logging forest compositions suggests that clearcutting at Roan Mountain's high elevations dramatically altered the spruce-fir forest.

The relative dominance, importance values, and understory survey suggest that the modern high- 

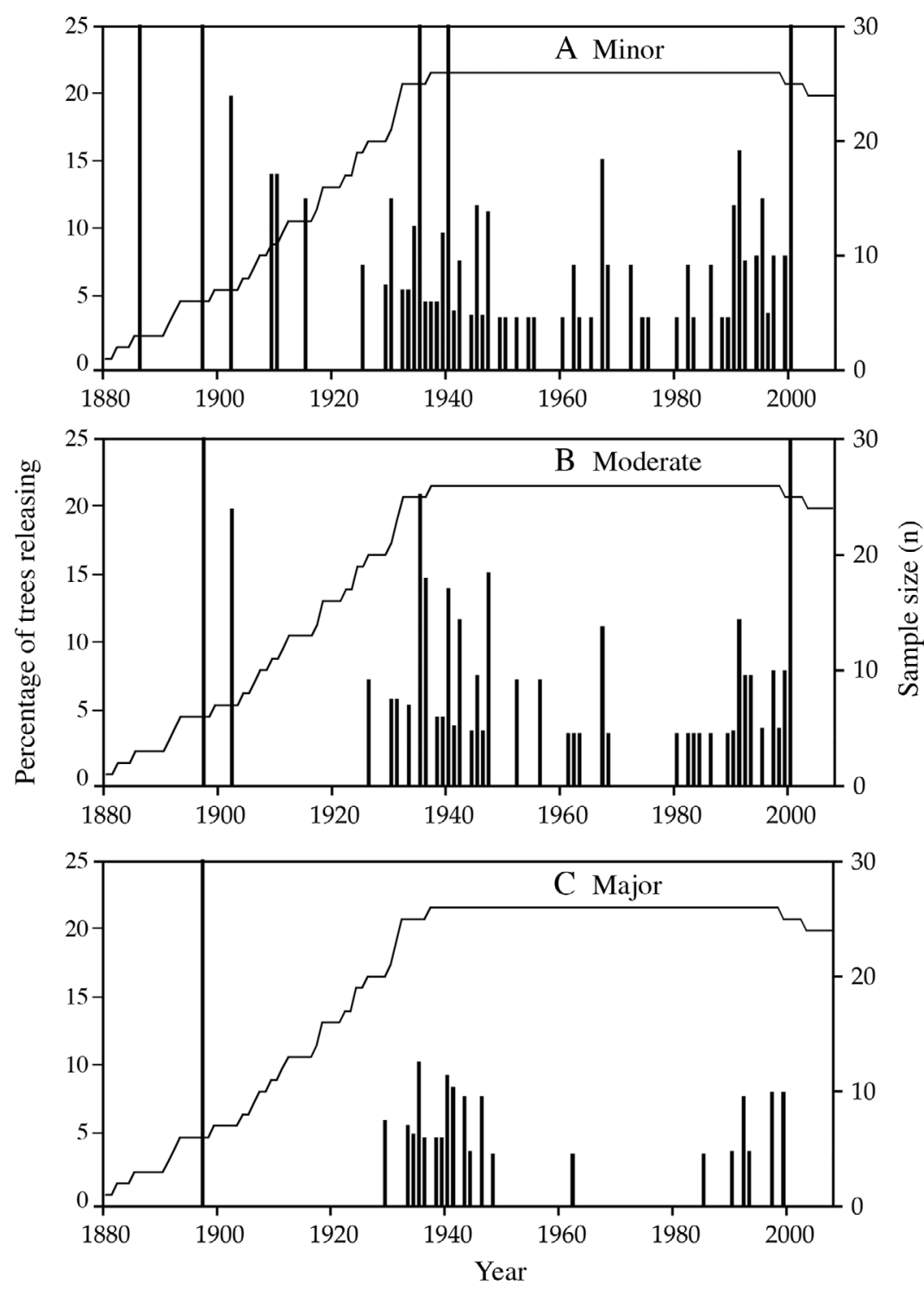

Fig. 4. Picea rubens. (A) Minor, (B) moderate, and (C) major release events in red spruce at Roan Mountain, North Carolina, using a 10 yr running mean. Vertical black bars represent the percentage of trees that experienced a release in that year. Horizontal black lines represent sample size. Releases in $25 \%$ or more of the living trees were considered a stand-wide release

elevation forest at Roan Mountain currently occupies an early to mid-successional stage (Oliver \& Larson 2002). Further, the high density of Fraser fir compared to red spruce indicates that the forest is in a relatively early stage of development, because Fraser fir is a pioneer species (Messier et al. 1999). Fraser fir also dominates the understory classes, indicating that insufficient time has passed for the shade tolerance of red spruce to confer a competitive advantage over Fraser fir.

The prevalence of the codominant canopy class suggests that the trees in this stand have formed a single, horizontal crown stratum typical of single-cohort stands. Trees growing as codominants, with few dominant trees emerging from the canopy, are spatially limited horizontally, as crowns are crowded from all sides by other trees. This forest condition is characteristic of a stand experiencing the stem exclusion and understory initiation stages of development (Oliver \& Larson 2002). As the Roan Mountain spruce-fir forest ages, Fraser fir dominance may slightly decrease as more shade-tolerant red spruce stems slowly reach the canopy. Fraser fir's dominant status will continue as the stand approaches old growth stage, albeit to a lesser extent, because fir typically occurs more frequently than red spruce above $1800 \mathrm{~m}$ in the southern Appalachian Mountains (Delcourt \& Delcourt 2000). In the absence of future major disturbances, Fraser fir will likely continue its dominance, although minor canopy disturbances may allow red spruce to increase in dominance. As the stand matures and aging Fraser fir trees become more susceptible to balsam woolly adelgid infestation, older Fraser firs will likely die. If the balsam woolly adelgid outbreak occurred with the successional decline of Fraser fir, red spruce could eventually become codominant, or in an extreme case, even dominant.

The disturbance history of the Roan Mountain spruce-fir forest is tied to its logging history, and all disturbances that have occurred during the short existence of the current forest should be considered in the context of its logging past. The stand-age and release event results demonstrate the effect logging had on forest development. Of the 3 minor and moderate stand-wide release events we detected, 2 (1935 and 1940) occurred after the cessation of logging. Localized disturbances occurred often during the post-logging era on both minor and moderate scales, while major releases occurred less frequently. These disturbances could be caused by the balsam woolly adelgid, which first appeared on Roan Mountain in 1962. Our analysis detected a major release event 


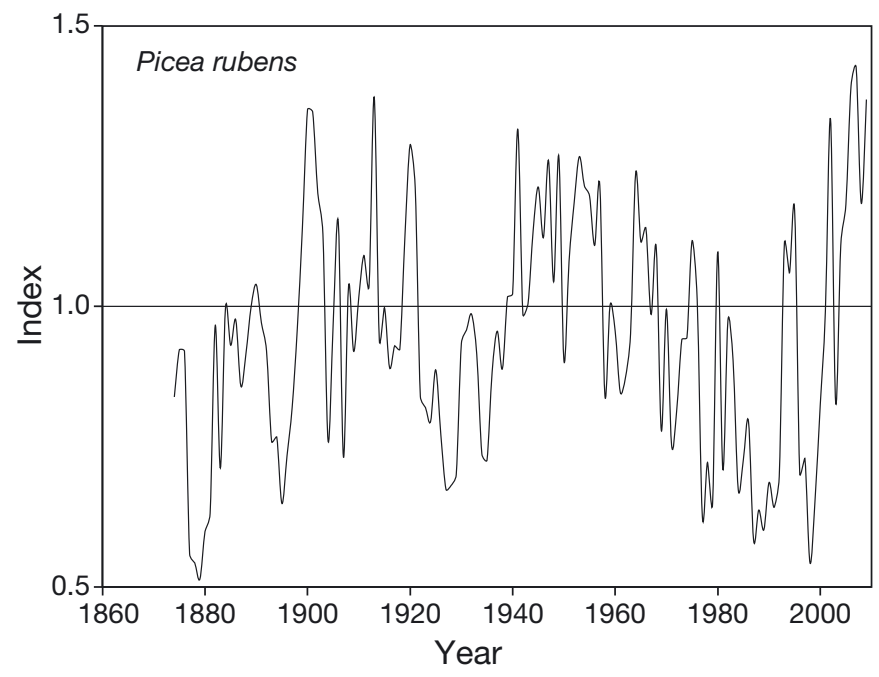

Fig. 5. Picea rubens. Ring-width index chronology generated from red spruce series at Roan Mountain, North Carolina (1874-2009). The mean radial growth is standardized to 1.0. Note periods of radial growth releases during the 1870s, 1890s, 1930s, 1980s, 1990s, and 2000s

Table 3. Picea rubens. Red spruce trees exhibiting minor, moderate, and major releases, total releases found in all trees, and mean number of releases per tree

\begin{tabular}{|lccc|}
\hline $\begin{array}{l}\text { Release } \\
\text { intensity }\end{array}$ & $\begin{array}{c}\text { Series with } \\
\text { releases }\end{array}$ & $\begin{array}{c}\text { Releases in } \\
\text { all trees }\end{array}$ & $\begin{array}{c}\text { Mean no. } \\
\text { releases tree }\end{array}$ \\
\hline Minor & 23 & 91 & 3.96 \\
$\begin{array}{l}\text { Moderate } \\
\text { Major }\end{array}$ & 21 & 62 & 2.95 \\
\hline
\end{tabular}

that year as well as a slight increase in minor and moderate release events from 1962 to the $1970 \mathrm{~s}$. None of these events, however, were stand-wide in nature, indicating that the effects of this initial infestation were perhaps not as severe at Roan Mountain as those documented in other areas of the southern Appalachians (Dull et al. 1988). We hypothesize that the relatively young age of this Fraser fir forest during the initial infestation limited the effects of the adelgid because juvenile Fraser firs are more resistant to infestation than mature trees (Potter et al. 2005). Therefore, the devastating logging of the 1930s may have mitigated the initial effects of the balsam woolly adelgid on the stand dynamics of Roan Mountain's spruce-fir forest over the past $80 \mathrm{yr}$.

A pattern of localized minor, moderate, and major release events during the mid-1980s, early 1990s, and 2000 indicates a broadly decadal cycle of disturbance episodes. These events were likely the result of major balsam woolly adelgid infestations. How- ever, the only documentation of Fraser fir dieback from the balsam woolly adelgid occurred during 1962, and our release event results do not show a clear balsam woolly adelgid infestation signal. It is difficult to assign these localized events solely to pulses in balsam woolly adelgid infestation, because thunderstorms, severe winds, and ice storms may cause a similar disturbance signal. The stand-wide disturbance event during 2000 may have been related to a weather event, but we suspect it was related to a southern pine beetle Dendroctonus frontalis Zimmermann infestation that affected red spruce on Roan Mountain (Billings 2011). Although the southern pine beetle does not commonly infest red spruce, there have been some observed incidents in the southeastern USA during warm and dry conditions (Thatcher et al. 1980).

During the 1980s, scientists were concerned about the decline in red spruce health. Research was conducted to investigate how climatic factors limit growth of red spruce across its range (Cook et al. 1987, Eagar \& Adams 1992). Previous studies found red spruce to be a useful indicator of climate change (Cook 1988), but little research on the species has taken place in the southern Appalachian Mountains since the 1980s, and the relationships between tree growth, climate, and stand dynamics in the southern Appalachian spruce-fir forest are not fully understood (Cook \& Zedaker 1992, Rentch et al. 2012). Future research related to climate change in RSFF forests should investigate how shifts in the climate regime affected RSFF forest productivity during recent decades.

\section{CONCLUSIONS}

Roan Mountain spruce-fir stands established between the 1880s and the early 1900s and are currently in the understory reinitiation stage. The stand-wide logging disturbance during the 1930s dramatically altered the composition and structure of the area's RSFF forest. The forest was clear-cut and is relatively even-aged. Tree-ring evidence from the RSFF forest indicated great differences between the historic and modern forests. Red spruce was formerly of greater importance in the RSFF community at Roan Mountain than it is currently. Red spruce tree rings showed high initial growth rates consistent with the stand initiation stage. The red spruce that survived logging during the 1930s showed that trees were greater in size and occupied upper canopy positions during the pre-logging period. The pre-log- 
ging forest also exhibited greater variation in age classes than the current forest. A cohort of Fraser fir trees that established following logging dominated the spruce-fir forest in the modern, post-logging era. The earlier successional advantage of Fraser fir over red spruce has resulted in an even-aged Fraser firdominant forest that occupies a relatively early stage of successional development. In the absence of future stand-wide disturbances, dominance of Fraser fir will continue.

RSFF forests are much less extensive today than during the late 19th century, and this forest type is now considered to be endangered (Noss et al. 1995). Forest management options in the central Appalachian Mountains have been addressed in recent studies (e.g. Hornbeck \& Kochenderfer 1998, Schuler et al. 2002, Rentch et al. 2007, 2010, Adams et al. 2010). Forest thinning is a possible management option to promote red spruce abundance in the central Appalachian Mountains (Rentch et al. 2010). However, management plans would need to be modified for the southern Appalachian Mountains. Logging disturbance would negatively impact associated endangered species endemic to the southern Appalachian Mountain spruce-fir ecosystem. Research on spruce-fir stand dynamics and endangered species in the southern Appalachian Mountains could use this study as baseline data representing spruce-fir forest conditions over the past $130 \mathrm{yr}$. Thus, this study provides a foundation for land managers in the southern Appalachian Mountains to develop longterm red spruce restoration plans.

Acknowledgements. This study was supported by a research grant from the North Carolina Native Plant Society, as well as graduate student awards from Appalachian State University. A. Cochran provided invaluable cartographic support. K. White, J. Holcolm, L. Bowman, W. Gandy, and B. White assisted with spruce-fir data collection. The Pisgah and Cherokee National Forests graciously provided research permits.

\section{LITERATURE CITED}

Adams MB, Eagar C (1992) Impacts of acidic deposition on high-elevation spruce-fir forests: results from the SpruceFir Research Cooperative. For Ecol Manag 51:195-205

Adams HS, Stephenson SL, Rollins AW, Adams MB (2010) The isolated red spruce communities of Virginia and West Virgina. Proc Conf Ecol Manag High-Elevation Forests in the Central and Southern Appalachian Mountains. GTRNRS-P-64. USDA Forest Service, Asheville, NC, p 1-12

Billings RF (2011) Use of chemicals for prevention and control of southern pine beetle infestations. In: Coulson RN, Klepzig KD (eds) Southern pine beetle II. GTR-SRS-140. USDA Forest Service, Asheville, NC, p 367-379
Boyce SG, Martin WH (1993) The future of the terrestrial communities of the southeastern coastal plain. In: Martin WH, Boyce SG, Echternacht AC (eds) Biodiversity of the southeastern United States: upland terrestrial communities. Wiley, New York, NY, p 339-366

Brown DM (1941) Vegetation of Roan Mountain: a phytosociological and successional study. Ecol Monogr 11: 61-97

Busing RT (2004) Red spruce dynamics in an old southern Appalachian forest. J Torrey Bot Soc 131:337-342

Busing RT, Clebsch EEC, Eagar C, Pauley EF (1988) Two decades of change in a Great Smoky Mountains sprucefir forest. Bull Torrey Bot Club 115:25-31

Busing RT, White PS, MacKenzie MD (1993) Gradient analysis of old spruce-fir forests of the Great Smoky Mountains circa 1935. Can J Bot 71:951-958

> Christensen NL, Bartuska AM, Brown JH, Carpenter S and others (1996) The report of the Ecological Society of America Committee on the scientific basis for ecosystem management. Ecol Appl 6:665-691

Christopherson RW (2006) Geosystems: an introduction to physical geography, 5th edn. Pearson Prentice Hall, Upper Saddle River, NJ

Clark SHB (2008) Geology of the Southern Appalachian Mountains: U.S. Geological Survey Scientific Investigations Map 2830. Available at http://pubs.usgs.gov/sim/ 2830/ (accessed 11 May 2010)

Cook ER (1985) A time series analysis approach to tree-ring standardization. PhD dissertation, University of Arizona, Tucson, AZ

Cook ER (1988) A tree ring analysis of red spruce in the southern Appalachian Mountains. In: Van Deusen PC (ed) Analyses of Great Smoky Mountain red spruce tree ring data. USDA Forest Service Gen Tech Rep SO-69. Southern Forest Experiment Station, New Orleans, LA, p 6-19

Cook ER, Zedaker SM (1992) The dendroecology of red spruce decline. In: Eagar C, Adams MB (eds) Ecology and decline of red spruce in the eastern United States. Springer Verlag, New York, NY, p 192-231

> Cook ER, Johnson AH, Blasing TJ (1987) Forest decline: modeling the effect of climate in tree rings. Tree Physiol 3:27-40

Cottam G, Curtis JT (1956) The use of distance measures in phytosociological sampling. Ecology 37:451-460

Delcourt HR, Delcourt PA (2000) Eastern deciduous forests. In: Barbour MG, Billings WD (eds) North American terrestrial vegetation, 2nd edn. Cambridge University Press, Cambridge, p 357-395

Dull CW, Ward JD, Brown HD, Ryan GW, Clerke WH, Uhler RJ (1988) Evaluation of spruce and fir mortality in the Southern Appalachian Mountains. Protection Report R8. USDA Forest Service, Southern Region, Atlanta, GA

Eagar C, Adams MB (1992) The ecology and decline of red spruce in the eastern United States. Springer-Verlag, New York, NY

Fraver S, White AS (2005) Identifying growth releases in dendrochronological studies of forest disturbance. Can J For Res 35:1648-1656

Fritts HC (1976) Tree rings and climate. Academic Press, New York, NY

Goelz JCG, Burk TE, Zedaker SM (1999) Long-term growth trends of red spruce and Fraser fir at Mt. Rogers, Virginia and Mt. Mitchell, North Carolina. For Ecol Manag 115: $49-59$ 
Grissino-Mayer HD (2001) Evaluating crossdating accuracy: a manual and tutorial for the computer program COFECHA. Tree-Ring Res 57:205-221

Hart JL, van de Gevel SL, Grissino-Mayer HD (2008) Land use and forest dynamics in a natural area of the southern ridge and valley, Tennessee. Nat Areas J 28:275-289

Hayes M, Moody A, White PS, Costanza JL (2007) The influence of logging and topography on the distribution of spruce-fir forests near their southern limits in Great Smoky Mountains National Park, USA. Plant Ecol 189: 59-70

Holmes RL (1983) Computer assisted quality control in treering dating and measurement. Tree-Ring Bull 43:69-78

Holmes RL (1999) Dendrochronology program library and the dendroecology program library. Laboratory of TreeRing Research, University of Arizona, Tucson, AZ www. ltrr.arizona.edu/pub/dpl-mac/68k/dpl.txt

Hornbeck JW, Kochenderfer JN (1998) Growth trends and management implications for West Virginia's red spruce forests. North J Appl For 15:197-202

Hornbeck JW, Smith RB (1985) Documentation of red spruce growth decline. Can J For Res 15:1199-1201

Johnson AH, Siccama TG (1983) Acid deposition and forest decline. Environ Sci Technol 17:294A-305A

Korstian CF (1937) Perpetuation of spruce on cut-over and burned lands in the higher southern Appalachian Mountains. Ecol Monogr 7:125-167

Lorimer CG, Frelich LE (1989) A methodology for estimating canopy disturbance frequency and intensity in dense temperate forests. Can J For Res 19:651-663

Ludwig JA, Reynolds JF (1988) Statistical ecology. J. Wiley, New York, NY

Matthews RW, Mackie ED (2007) Forest mensuration: a handbook for practitioners. Forestry Commission, Edinburgh

McLaughlin SB, Andersen CP, Hanson PJ, Tjoelker MG, Roy WK (1991) Increased dark respiration and calcium deficiency of red spruce in relation to acidic deposition at high-elevation southern Appalachian Mountain sites. Can J For Res 21:1234-1244

Messier C, Doucet R, Ruel JC, Claveau Y, Kelly C, Lechowicz MJ (1999) Functional ecology of advance regeneration in relation to light in boreal forests. Can J For Res 29: 812-823

Noss RF, LaRoe ET, Scott JM (1995) Endangered ecosystems of the United States: a preliminary assessment of loss and degradation. Biol Rep 28. USDI National Biological Service, Washington, DC

Nowacki GJ, Abrams MD (1997) Radial-growth averaging criteria for reconstructing disturbance histories from presettlement origin oaks. Ecol Monogr 67:225-249

NRCS (Natural Resource Conservation Service) (2010) Soil survey. Available at http://websoilsurvey.nrcs.usda.gov/

Editorial responsibility: Hans Juergen Boehmer, Bonn, Germany
app/WebSoilSurvey.aspx (accessed 11 May 2010)

Oliver CD, Larson BC (2002) Forest stand dynamics. McGraw-Hill, New York, NY

Orwig DA, Abrams MD (1994) Land-use history (17201992), composition, and dynamics of oak-pine forests within the Piedmont and Coastal Plain of northern Virginia. Can J For Res 24:2141-2149

Potter KM, Frampton J, Sidebottom JR (2005) Impacts of balsam woolly adelgid on the southern Appalachian sprucefir ecosystem and on the North Carolina Christmas tree industry. In: Proc 3rd Symp Hemlock Woolly Adelgid in the eastern United States, Asheville, NC, p 104-114

Pyle C (1984) Pre-park disturbance in the spruce-fir forests of Great Smoky Mountains National Park. In: White PS (ed) The southern Appalachian spruce-fir ecosystem: its biology and threats. Research/Resource Management Report SER-71. USDI National Park Service, Atlanta, GA

Pyle C, Schafale MP (1988) Land use history of three sprucefir forest sites in the southern Appalachians. J For Hist 32:4-21

> Rentch JS, Schuler TM, Ford WM, Nowacki GJ (2007) Red spruce stand dynamics, simulations, and restoration opportunities in the Central Appalachians. Restor Ecol 15:440-452

Rentch JS, Schuler TM, Nowacki GJ, Beane NR, Ford WM (2010) Canopy gap dynamics of second-growth red spruce-northern hardwood stands in West Virginia. For Ecol Manag 260:1921-1929

Rubino DL, McCarthy BC (2004) Comparative analysis of dendroecological methods used to assess disturbance events. Dendrochronologia 21:97-115

Schuler TM, Ford WM, Collins RJ (2002) Successional dynamics and restoration implications of a montane coniferous forest in the central Appalachians. Nat Areas J 22:88-98

Smith GF, Nicholas NS (1999) Post-disturbance spruce-fir forest stand dynamics at seven disjunct sites. Castanea 64:175-186

> Smith GF, Nicholas NS (2000) Size- and age-class distributions of Fraser fir following balsam woolly adelgid infestation. Can J For Res 30:948-957

Stokes MA, Smiley TL (1996) An introduction to tree-ring dating. University of Arizona Press, Tucson, AZ

Thatcher RC, Searcy JL, Coster JE, Hertel GD (1980) The southern pine beetle. Tech Bull 1631. USDA Forest Service, Expanded Southern Pine Beetle Research and Application Program, Science and Education Administration, Pineville, LA

Wear DN, Greis JG (2002) Southern forest resource assessment: summary of findings. J For 100:6-15

Wilson JB (1991) Roan Mountain: a passage of time. Blair, Winston-Salem, NC

Submitted: December 2, 2011; Accepted: March 6, 2012

Proofs received from author(s): June 20, 2012 